\title{
COMPARATIVE GERMINATION RESPONSES OF COWPEA AND MAIZE GENOTYPES TO SOIL MOISTURE CONTENT
}

\author{
ABAYOMI, Y.A. AND ADENIYI A.M. \\ Department of Agronomy, University of Ilorin, Nigeria
}

\begin{abstract}
:
Germination, emergence and establishment phase are critical to the growth cycle of plant as it determines the density of the stand obtained. However, a number of factors including soil available moisture decrease seed germination and the rate of decline is found to vary with crop species. Pot experiment was therefore conducted to evaluate the germination responses of cowpea (Vigna unguiculata (L.) Walp.) and maize (Zea mays, L) genotypes to varying soil available moisture. Seeds of ten varieties each of cowpea and maize were germinated at three available soil moisture contents $(25 \%, 50 \%$ and $100 \%$ field capacity). The moisture contents were determined gravimetrically. An experimental unit was a $10 \mathrm{~L}$ pot filled with $10 \mathrm{Kg}$ top soil, planted with 25 seeds and moistened to the required soil moisture content. Daily emergence was recorded from 5 days after planting (DAP) to 15 DAP. Data collected were used to estimate germination percentage (E\%) and speed of germination as mean germination time (MGT). Both the speed of germination and final germination percentage were significantly decreased by inadequate soil moisture (25\%) in both cowpea and maize with greater effect on cowpea which also showed greater genotypic variations in germinability at the sub-optimal moisture condition than maize. Speed of germination and germination percentage in cowpea were also reduced at water saturation condition (100\%), while maize gave the best results at this moisture content. These results therefore suggest that both inadequate and too much soil moisture conditions are detrimental to seed germination in cowpea, while maize can tolerate the two conditions. Nevertheless, non-significant interactions of soil moisture and crop species suggest similar responses of genotypes of both species to soil available moisture, but with greater magnitudes in cowpea genotypes.
\end{abstract}

Key words: Soil moisture content, crop species germination, cowpea and maize.

\section{INTRODUCTION:}

The importance of crop establishment in crop productivity can not be over emphasized. Of all factors controlling productivity, seed germination and vigour are prerequisites for the success of stand establishment in crop plants. Proper germination of planted seeds and the rate and degree of subsequent seedling establishment are of great importance in determining both yield and time of maturity (Brigg and Aytenfisu, 1979). However, a number of factors including inadequate available soil moisture decreases seed germination (Etejere, 2004). Germination of most seeds depends mainly on the amount of moisture that is available to the seeds (Finch-Savage et al., 1994).

Germination rates have been reported to decrease at low available water and the rate of decline was found to vary with crop species and genotypes (Smith et al, 1989, 
Abayomi and Saliu, 1997) and each species appear to require the absorption of certain amount of moisture to germinate (Smith et al, 1989). The differential ability of each species to germinate at low moisture content is heritable and is used as a criterion for selecting for drought tolerance in crops (Ashraf and Abu-Shakra, 1978; Lafond and Baker, 1986). Germination is inhibited by moisture stress through a reduction in imbibition process and by delaying metabolic and mobilization processes (Hank and Thorp, 1956).

Cowpea and maize are important legume and cereal crops in Nigeria. However, the availability of water is a major factor limiting their production in most areas of the world, including Nigeria. It is therefore important to establish the critical soil moisture content for germination and to identify the genotypes of the two crop species that can germinate and establish at reduced soil moisture. It is therefore the objectives of this study to evaluate the effects of soil moisture content on seed germination in cowpea and maize and to compare the responses of genotypes of the two species to sub-optimal soil moisture.

\section{MATERIALS AND METHODS:}

This study was conducted in pot experiment at the crop pavilion of the Department of Agronomy, University of Ilorin, Ilorin, Nigeria. The experiment was designed as a $2 \times 3 \times 10$ factorial and laid out in split-split-plot arrangements with two crop species (cowpea and maize) as the main plots, three soil moisture contents $(25,50$ and $100 \% \mathrm{FC}$ ) the sub-plots and ten genotypes as the sub-sub-plots. The cowpea genotypes tested include IT97K-356-1, IT97K-499-38, 1T98K-491-4, ITA 352, IT00K901-5, ITA271, IT97K-598-18, IT98K-131-2, IT99K-1060 and IT99K-1245; while maize genotypes include EV IWD STR Co; TZL COMP 4 C2, TZL COMP 3 C2, SIN 93 TZL STR-W, AK 94 DMR-ESRY, 9134-14, 8535-23, 2021-18STR and 9044-27 STR. All the genotypes were obtained from the International Institute of Tropical Agriculture (IITA), Ibadan, Nigeria.

Each experimental unit was a ten litre pot $(10 \mathrm{~L})$ filled with $10 \mathrm{Kg}$ top soil, moistened to the required soil moisture content $(25,50$ or $100 \% \mathrm{FC})$ determined gravimetrically (Kramer, 1983; Abayomi, 1996) and maintained at the appropriate moisture content by periodic addition of water as required. Twenty-five (25) seeds of the appropriate species/ genotype were planted in each pot. Data collection was on daily seedling emergence counts from 5 - 15 DAP. The emergence data were later used to estimate germination percentage $(\mathrm{E} \%)$ and speed of germination as mean germination time (MGT) as described by Abayomi and Saliu (1997):

$$
\begin{array}{rlr}
\mathrm{E} \%= & \begin{array}{c}
\text { No of emerging seedlings at } 15 \text { DAP } \\
\text { Total number of seeds planted }
\end{array} & 100 \\
\text { NGT }= & \text { No of seeds germinating in day x X } & \text { DAP } \\
\hline \text { Total number of seeds germinated at } & 15 \text { DAP }
\end{array}
$$


These values were estimated for each experimental unit, and all data were subjected to the analysis of variance (ANOVA) using split-split-plot model. Significant means were separated by the Duncan's Multiple Range Test at 5 percent probability level.

\section{RESULTS AND DISCUSSION}

The results of this study showed that the onset of germination was delayed by inadequate soil moisture. The total seed germination was significantly $(p<0.001)$ decreased in both crop species (Fig. 1). The effects were greater on cowpea than in maize across all genotypes and soil moisture contents (Fig. 2a). The ability of seeds to germinate at low soil moisture content have been shown to depend on crop species (Ashraf and Abu-Shakra, 1978). The comparative responses of in this study show that both crop species showed significant genotypic variations in germinability at $25 \%$ soil moisture content with greater differences in cowpea in which germination was mostly below 50 percent (Table 1). These results are in line with the reports of other workers who had earlier shown that water stress can affect germination by delaying its onset, slowing its rate, or by decreasing the final germination percentage (Delouche et al, 1982; Smith and Hoveland, 1986; Jain and Patel, 1988;).

It has been observed that germination at low soil available moisture is inhibited through a reduction in imbibition process and by delaying metabolic and mobilization processes (Hanks and Thorp, 1956). Similarly, Humbert (1968) has reported that transition from dormancy to germinating stage is characterized by changes in food constituent and sugar which are triggered by moisture. Thus delayed and / or inadequate irrigation have been shown to result in loss of germination in sugar cane (Abayomi et al, 1990). Consequently the need for moisture to trigger the shift from dormancy to activity could then explain the lower germination obtained at $25 \%$ soil moisture in this study.

In both crop species, the speed of germination measured as the mean germination time $(\mathrm{MGT})$ increased significantly $(\mathrm{p}<0.01)$ (reduced MGT) with increasing soil available moisture in all genotypes (Table 2). However, the reduction in germination speed (high MGT) due to inadequate moisture was greater in cowpea than in maize (Fig. 2b). Choudhry (1960) has earlier shown that the application of adequate moisture resulted in germination at a rate twice those with inadequate moisture. Other workers have shown that MGT increased (decreased speed) with increasing osmotic potential (decreasing available moisture) (Lafond and Baker, 1986; Smith et al, 1989; Abayomi and Saliu, 1997; Abayomi and Wright, 1999). The decrease in germination rate, shown by high MGT, due to inadequate soil moisture obtained in the present study was due to reduced water uptake by the germinating seeds at the sub-optimal moisture condition in line with the observation of Parman and Moore (1968) and Ashraf and Abu-Shakra (1978).

Many investigators have earlier concluded from their studies with other crops that seed germination at sub-optimal available moisture is an efficient technique for screening 
crop plants for water stress tolerance (Ashraf and Abu-Shakra, 1978; Abayomi, 1992). The results of the present study show that maize genotypes germinated better than $(\mathrm{p}<$ 0.001 ) cowpea genotypes at both 25 and $100 \%$ moisture content, while there were no appreciable differences at 50\% moisture content (Table 1). Similarly, the differential germination responses to inadequate and excessive moisture conditions were greater in cowpea genotypes than in maize, thereby suggesting that germination in cowpea is more sensitive to soil available moisture conditions, decreasing under low and excessive moisture conditions, both of which are better tolerated by maize genotypes. The results of the present study showed significant species and genotype differences in germination at sub-optimal soil moisture conditions and hence in line with the earlier reports, thereby suggesting that maize genotypes are more tolerant of water stress than cowpea genotypes. Consequently, from the results of this study, IT00K-901-5 and EV IWOSTR C0 are the most water stress tolerant cowpea and maize genotype respectively.

\section{REFERENCES:}

Abayomi, Y. A. (1992). Comparative effects of water stress on wheat and sugar beet. Ph.D Thesis, (unpublished) University of Wales, United Kingdom.

Abayomi, Y.A.; Etejere E.O.; Fadayomi R. O. (1990) "Effects of stalk section, coverage depth and date of first irrigation on seed cane germination of two commercial sugar cane cultivars in Nigeria" Turrialba 40 (1): 58-62.

Abayomi, Y.A. (1996) "Interactive effects of moisture, nitrogen and phosphorus fertilizers on growth and biomass yield of a commercial sugar cane cultivar CO 957' Bioscience Research Communications 8(1): 57-67.

Abayomi, Y. A. and Saliu L.O.,(1997), "Emergence and seedling vigour responses to simulated sub-optimal moisture condition in twelve open-pollinated maize (Zea mays, L) varieties" Bioscience Research Communications 9(1): 21-28.

Abayomi, Y.A. and D. Wright (1999) "Osmotic potential and temperature effects on germination of spring wheat genotypes (Triticum aestivum, L)" Tropical Agriculture (Trinidad) 76(2): 114-119.

Ashraf, C. M. and Abu-Shakra S, (1978) "Wheat seed germination under low temperature and moisture stress" Agron J. 70: 135-139.

Brigg, K.G. and Aytenfisu A. (1979) "The effect of seeding rate, seeding date and location on grain yield, maturity, protein percentage and protein yield of some spring wheat in Central Alberta" Can. J. Plant Science 59:1129-1146.

Choudhry, J.K. (1960) "Effect of irrigation with ammonium sulphate on the growth, yield and quality of sugar cane (CO 453)" Indian Agriculture 4: 33-43.

Delouche, J.C.; Andrews C.; Potts H.; Revsche H.C and Cabrera E. (1982) "Seed factors influencing germination and seed establishment" Annual Report Intsormil Project X11/MZU1.

Etejere, E.O. (2004). The seed sower and the germination dilemma. $73^{\text {rd }}$ Inaugural Lecture, University of Ilorin. Unilorin Library and Publication Committee. 33p.

Finch-Savage, W.E.; Phelps K. and Steckel J.R.A. (1994). Fourth National Symposium on stand establishment of horticultural crops. Davis C.A. pp 103-108.

Hanks, R.S. and Thorp F.C. (1956). Proc. Soil Science Society of America 20: 207-310.

Humbert, R.P. (1968). The growing of Sugar cane. Amsterdam, Elsevier Publishing Company. 870p. 
Jain R.P and Patel K. R. (1988). Germination of pearl millet (Pennisetum americanum, (L) Leek) under varying level of osmotic potential of PEG 6000. J. Agric. Sci. (Cambridge) 110: 419-421.

Kramer, P.J. (1983). Water Relations of Plant. New York, Academic Press.

Lafond, G. P. and Baker R.J., 1986). Effects of temperature and moisture stress and seed size on germination of nine spring wheat cultivars. Crop Science 26:563-567.

Parman M.T. and Moore R.P (1968). Effect of simulated drought by polyethylene glycol solutions on corn (Zea mays, L) germination and seedling development. Agron. J. 58:391-392.

Smith, R.L and Hoveland C.S. (1986). Effect of temperature and water stress on seed germination and seedling depth on emergence of pearl millet and sorghum. Agronomy Abstracts ASA, Madison, WI USA. P.94.

Smith, R.L.; Hoveland C.J. and Hanna W.W. (1989). Water stress and temperature in relation to seed germination of pearl millet and sorghum. Agron. J. 81: 303-305 


\section{Table 1. Interactive effects of soil moisture on germination percentage of cowpea and maize genotypes}

\begin{tabular}{|c|c|c|c|c|}
\hline \multirow[b]{2}{*}{ Species } & \multicolumn{4}{|c|}{ Moisture content $(\%)$} \\
\hline & Genotype & 25 & 50 & 100 \\
\hline \multirow[t]{10}{*}{ Cowpea } & IT97K-356-1 & $50.7 \mathrm{bc}$ & $70.0 \mathrm{~b}$ & $36.7 \mathrm{f}$ \\
\hline & IT97K-499-38 & $46.7 \mathrm{c}$ & $86.7 \mathrm{ab}$ & $66.7 \mathrm{bcd}$ \\
\hline & IT98K-491-4 & $43.3 c$ & $70.0 \mathrm{~b}$ & $40.0 \mathrm{ef}$ \\
\hline & ITA 352 & $40.0 \mathrm{c}$ & $86.7 \mathrm{ab}$ & $80.0 \mathrm{abc}$ \\
\hline & IT00K-901-5 & $76.7 \mathrm{a}$ & $93.3 \mathrm{ab}$ & $63.3 \mathrm{bcde}$ \\
\hline & ITA 271 & $30.0 \mathrm{c}$ & $90.0 \mathrm{ab}$ & $60.0 \mathrm{cdef}$ \\
\hline & IT97K-598-18 & $40.0 \mathrm{c}$ & $76.7 \mathrm{ab}$ & $53.3 \mathrm{def}$ \\
\hline & IT98K-131-2 & $36.7 \mathrm{c}$ & $96.7 \mathrm{a}$ & $80.0 \mathrm{abc}$ \\
\hline & IT99K-1060 & $50.0 \mathrm{bc}$ & $90.0 \mathrm{ab}$ & $83.3 \mathrm{abc}$ \\
\hline & IT99K-1245 & $53.3 \mathrm{bc}$ & $93.3 \mathrm{ab}$ & 78.7abcd \\
\hline \multirow[t]{10}{*}{ Maize } & EV IWOSTR C0 & $93.3 \mathrm{a}$ & $93.3 \mathrm{ab}$ & $96.7 \mathrm{a}$ \\
\hline & TZL COMP 4 C2 & $73.3 \mathrm{ab}$ & $96.7 \mathrm{a}$ & $93.3 \mathrm{a}$ \\
\hline & TZL COMP 3 C2 & $90.0 \mathrm{a}$ & $96.7 \mathrm{a}$ & $100 \mathrm{a}$ \\
\hline & SIN 93 TZU TSR-W & 73.3ab & $96.7 \mathrm{a}$ & $100 \mathrm{a}$ \\
\hline & AK 94 DMR-ESRY & $80.0 \mathrm{a}$ & $100 \mathrm{a}$ & $100 \mathrm{a}$ \\
\hline & 9134-14 & $80.0 \mathrm{a}$ & $100 \mathrm{a}$ & $96.7 \mathrm{a}$ \\
\hline & $9121-14$ & $80.0 \mathrm{a}$ & $93.3 \mathrm{a}$ & $86.7 \mathrm{ab}$ \\
\hline & $8535-23$ & $86.7 \mathrm{a}$ & $93.3 \mathrm{a}$ & $100 \mathrm{a}$ \\
\hline & 2021-18STR & $90.0 \mathrm{a}$ & $96.7 \mathrm{a}$ & $100 \mathrm{a}$ \\
\hline & 9044-27 STR & $86.7 \mathrm{a}$ & $100 \mathrm{a}$ & $100 \mathrm{a}$ \\
\hline
\end{tabular}

Figures followed by the same letter(s) in each column are not significantly different by Duncan's Multiple Range Test at 5 percent probability level. 
Table 2. Interactive effects of soil moisture on mean germination time (MGT, days) of cowpea and maize genotypes.

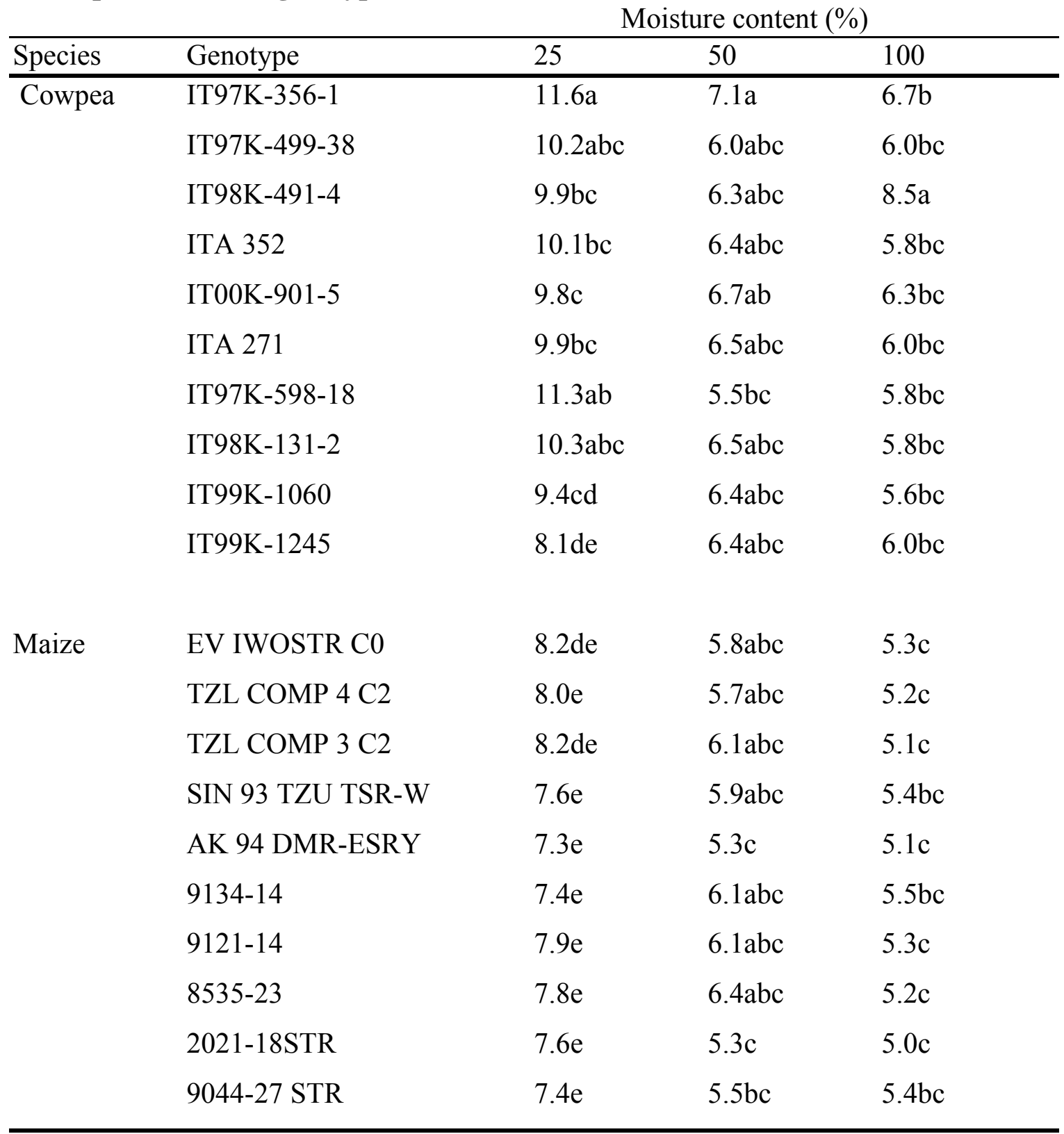

Figures followed by the same letter(s) in each column are not significantly different by Duncan's Multiple Range Test at 5 percent probability level. 
a

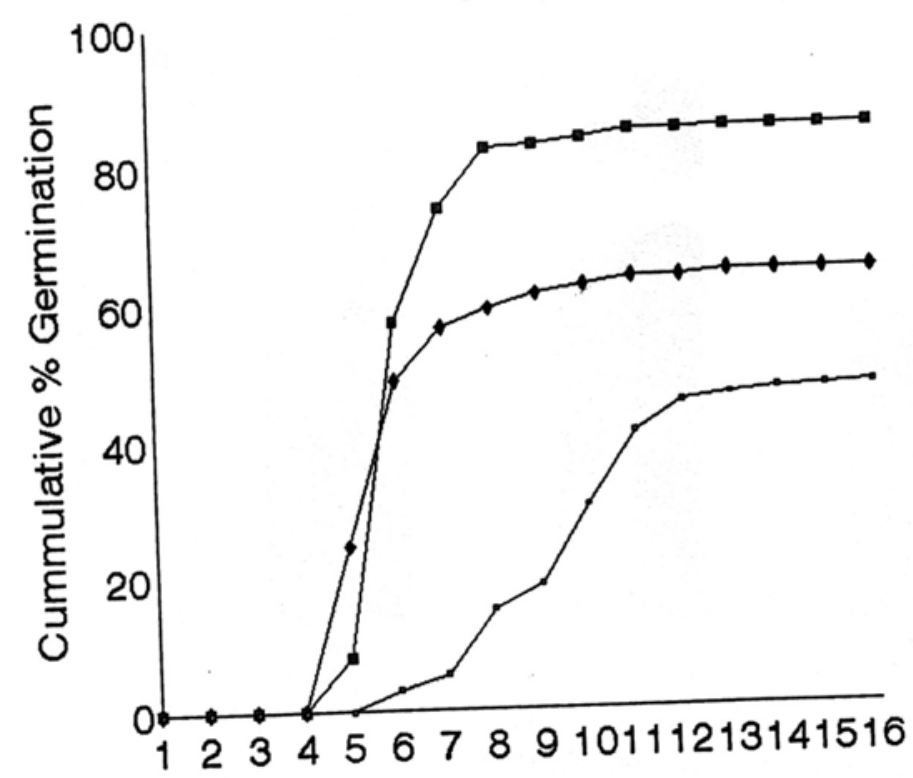

Moisture content (\%)

$-25$

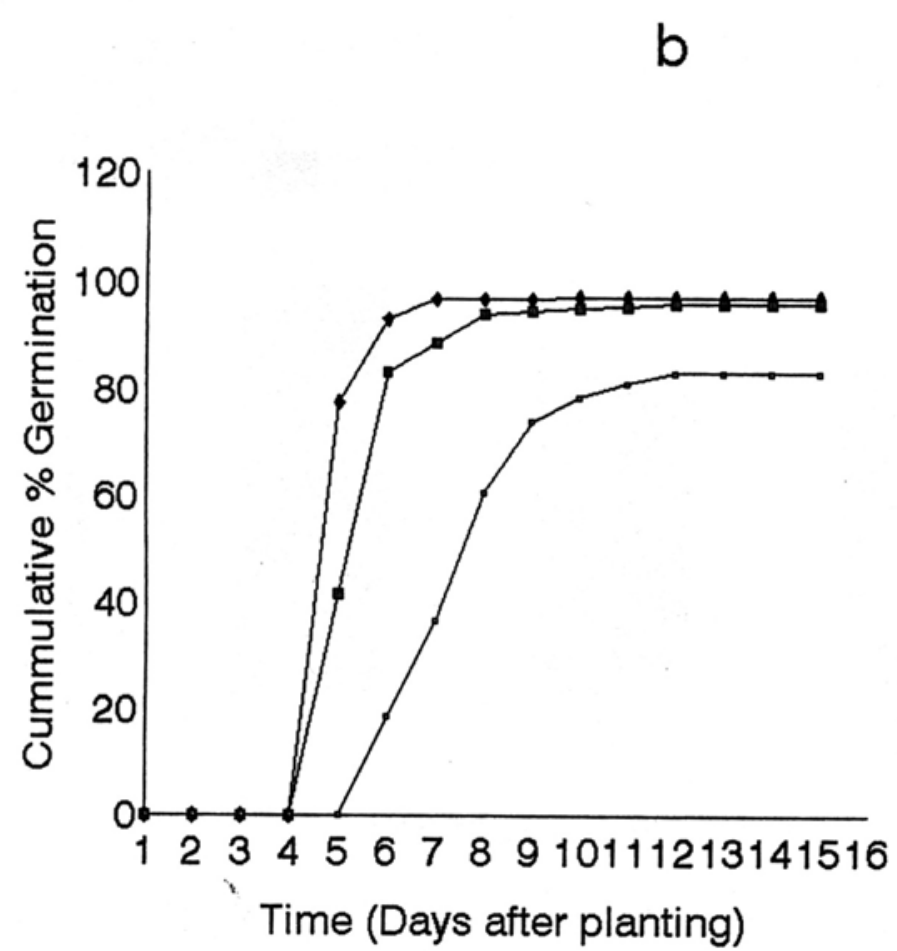

Fig.1 Effect of soil moisture content on percent germination of (a) cowpea and (b) maize. 

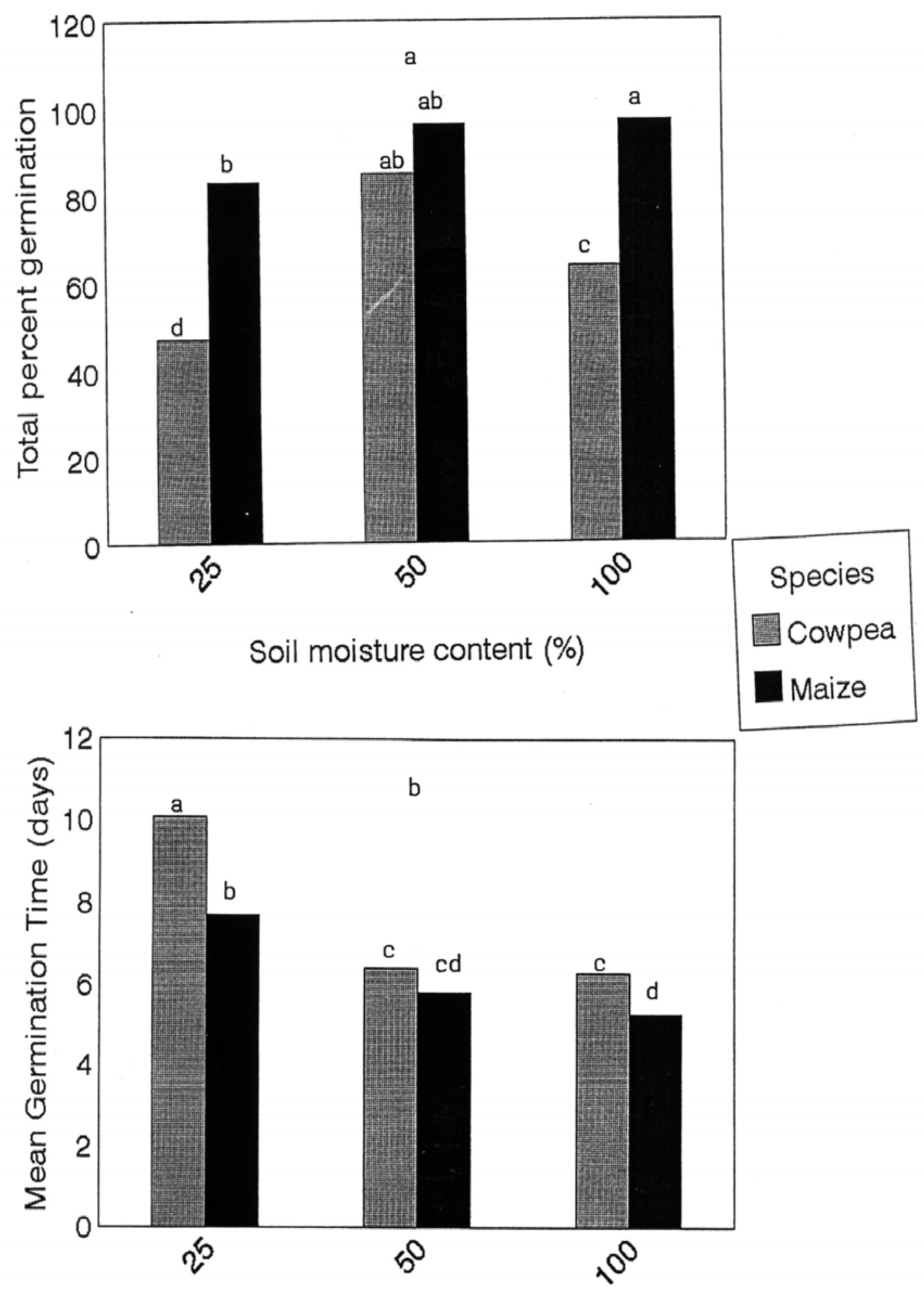

Soil moisture content (\%)

Fig. 2. Interactive effects of crop species and soil moisture on (a) \%Germination and (b) MGT. 